\title{
Can chest high-resolution computed tomography findings diagnose pulmonary alveolar microlithiasis?"
}

\author{
Podem os achados na tomografia computadorizada de alta resolução do tórax ser diagnósticos \\ de microlitíase alveolar pulmonar?
}

\section{Flávia Angélica Ferreira Francisco ${ }^{1}$, Rosana Souza Rodrigues² ${ }^{2}$, Miriam Menna Barreto ${ }^{3}$, Dante Luiz Escuissato ${ }^{4}$, Cesar Augusto Araujo Neto ${ }^{5}$, Jorge Luiz Pereira e Silva ${ }^{5}$, Claudio S. Silva ${ }^{6}$, Bruno Hochhegger ${ }^{7}$, Arthur Soares Souza $\mathrm{Jr}^{8}$, Gláucia Zanetti ${ }^{9}$, Edson Marchiori ${ }^{10}$}

Francisco FAF, Rodrigues RS, Barreto MM, Escuissato DL, Araujo Neto CA, Pereira e Silva JL, Silva CS, Hochhegger B, Souza Jr AS, Zanetti G, Marchiori E. Can chest high-resolution computed tomography findings diagnose pulmonary alveolar microlithiasis? Radiol Bras. 2015 Jul/Ago;48(4):205-210.

Abstract Objective: The present study was aimed at retrospectively reviewing high-resolution computed tomography (HRCT) findings in patients with pulmonary alveolar microlithiasis in order to evaluate the frequency of tomographic findings and their distribution in the lung parenchyma. Materials and Methods: Thirteen patients ( 9 females and 4 males; age, 9 to 59 years; mean age, 34.5 years) were included in the present study. The HRCT images were independently evaluated by two observers whose decisions were made by consensus. The inclusion criterion was the presence of abnormalities typical of pulmonary alveolar microlithiasis at HRCT, which precludes lung biopsy. However, in 6 cases lung biopsy was performed.

Results: Ground-glass opacities and small parenchymal nodules were the predominant tomographic findings, present in $100 \%$ of cases, followed by small subpleural nodules (92.3\%), subpleural cysts (84.6\%), subpleural linear calcifications (69.2\%), crazy-paving pattern (69.2\%), fissure nodularity (53.8\%), calcification along interlobular septa (46.2\%) and dense consolidation (46.2\%).

Conclusion: As regards distribution of the lesions, there was preferential involvement of the lower third of the lungs. No predominance of distribution in axial and anteroposterior directions was observed.

Keywords: Pulmonary alveolar microlithiasis; High-resolution computed tomography; Pulmonary calcifications.

Resu mo Objetivo: Analisar, retrospectivamente, as tomografias computadorizadas de alta resolução (TCAR) de pacientes com microlitíase alveolar pulmonar, a fim de avaliar a frequência dos padrões tomográficos e sua distribuição no parênquima pulmonar.

Materiais e Métodos: 0 estudo incluiu 13 pacientes ( 9 femininos e 4 masculinos) com idades variando de 9 a 59 anos (média de 34,5 anos). Os exames foram avaliados por dois observadores, de modo independente, e os casos discordantes, resolvidos por consenso. O critério de inclusão foi a presença de anormalidades na TCAR típicas de microlitíase alveolar pulmonar, o que prescinde a necessidade de exame histopatológico. Entretanto, em 6 casos foram realizadas biópsias pulmonares.

Resultados: Os achados tomográficos predominantes foram opacidades em vidro fosco e pequenos nódulos parenquimatosos, presentes em $100 \%$ dos casos, seguidos de pequenos nódulos subpleurais $(92,3 \%)$, cistos subpleurais $(84,6 \%)$, calcificações lineares subpleurais $(69,2 \%)$, padrão de pavimentação em mosaico $(69,2 \%)$, fissura nodular $(53,8 \%)$, calcificação ao longo dos septos interlobulares (46,2\%) e consolidações densas (46,2\%).

Conclusão: Quanto à distribuição dos achados, houve acometimento preferencial dos terços inferiores. Não foi observado predomínio de distribuição dos sentidos axial e anteroposterior.

Unitermos: Microlitíase alveolar pulmonar; Tomografia computadorizada de alta resolução; Calcificações pulmonares.

* Study developed at Hospital Universitário Clementino Fraga Filho da Universidade Federal do Rio de Janeiro (UFRJ), Rio de Janeiro, RJ, Brazil.

1. Fellow PhD degree, Program of Post-graduation in Radiology, Universidade Federal do Rio de Janeiro (UFRJ), Rio de Janeiro, RJ, Brazil.

2. PhD, Professor, Program of Post-graduation in Radiology, Universidade Federal do Rio de Janeiro (UFRJ), Physician at the Service of Radiology, Hospital Universitário Clementino Fraga Filho da Universidade Federal do Rio de Janeiro (UFRJ) and Instituto D'Or de Pesquisa e Educação, Rio de Janeiro, RJ, Brazil.

3.PhD, Professor, Program of Post-graduation in Radiology, Universidade Federa do Rio de Janeiro (UFRJ), Physician at the Service of Radiology, Hospital Universitário Clementino Fraga Filho da Universidade Federal do Rio de Janeiro (UFRJ), Rio de Janeiro, RJ, Brazil.

4. PhD, Associate Professor of Radiology, Department of Medical Practice, Universidade Federal do Paraná (UFPR), Curitiba, PR, Brazil.

5. PhDs, Associate Professors, Department of Medicine and Diagnostic Support, Universidade Federal da Bahia (UFBA), Salvador, BA, Brazil.
6. MD, Radiology Department, Facultad de Medicina Clinica Alemana, Universidad del Desarrollo Santiago, Chile.

7. PhD, Associate Professor of Imaging Diagnosis, Universidade Federal de Ciências da Saúde de Porto Alegre (UFCSPA), Porto Alegre, RS, Brazil.

8. PhD, Professor, Faculdade de Medicina de São José do Rio Preto (Famerp), São José do Rio Preto, SP, Brazil.

9. PhD, Professor, Program of Post-graduation in Radiology at Universidade Federal do Rio de Janeiro (UFRJ), Rio de Janeiro, Professor of Medical Practice, Faculdade de Medicina de Petrópolis, Petrópolis, RJ, Brazil.

10. PhD, Full Professor Emeritus, Universidade Federal Fluminense (UFF), Niterói, RJ, Associate Professor, Universidade Federal do Rio de Janeiro (UFRJ), Rio de Janeiro, RJ, Brazil.

Mailing Address: Dr. Edson Marchiori. Rua Thomaz Cameron, 438, Valparaíso. Petrópolis, RJ, Brazil, 25685-120. E-mail: edmarchiori@gmail.com.

Received November 17, 2014. Accepted after revision February 13, 2015. 


\section{INTRODUCTION}

Pulmonary alveolar microlithiasis (PAM) is a rare recessive autosomal disease characterized by intra-alveolar deposition of spherical calcified concretions (called calciferites, calcopherites or microliths), in the absence of any known calcium metabolism disorder. Most patients are asymptomatic at the moment of the diagnosis, and usually the disease is incidentally detected during routine exams, although it may be diagnosed during investigation on the familial history of the individual presenting with $\mathrm{PAM}^{(1,2)}$.

PAM is described in patients at different ages, with a long and progressive course that may lead to deterioration of the pulmonary function ${ }^{(2)}$. The affected individuals generally become symptomatic at the third or fourth decades of life. The disease may occur either sporadically or within the family, with $33 \%$ of the cases being hereditary following an autosomal recessive inheritance pattern ${ }^{(1,2)}$. PAM pathogenesis has been attributed to mutation in the gene (SLC34A2) that encodes a type IIb sodium-dependent phosphate transporter involved in the phosphate homeostasis in different organs including the lungs, which induces excess phosphate accumulation, favoring the development of microliths ${ }^{(3)}$.

Due to the marked dissociation between radiological features and clinical presentation of PAM, the diagnosis is sometimes based only on radiological findings ${ }^{(1)}$. High resolution computed tomography (HRCT) plays a very important role in the diagnosis of patients with suspected PAM, as HRCT findings are so characteristic that further diagnostic investigations such as histopathological analysis are generally unnecessary, particularly in patients whose families have other members with the disease $\mathrm{e}^{(1)}$.

The present study was aimed at analyzing, by means of HRCT in 13 PAM patients, the most frequent tomographic findings and their distribution in the pulmonary parenchyma.

\section{MATERIALS AND METHODS}

Retrospective and descriptive study of chest HRCTs of 13 PAM patients randomly selected by means of personal contacts with radiologists in ten different institutions in seven Brazilian states and one institution in Chile, in the period between 2007 and 2014. Nine of the 13 patients were women $(69.2 \%)$ and 4 were men $(30.8 \%)$, with ages ranging between 9 and 59 years (mean of 34.46 years) and median of 31 years. The study was approved by the Committee for Ethics in Research of Hospital Universitário Clementino Fraga Filho Universidade Federal do Rio de Janeiro, Rio de Janeiro, RJ, Brazil.

The diagnoses were made from chest HRCTs based upon the observation of typical patterns of the disease. However, 6 patients were also submitted to lung biopsy, which allowed for histological confirmation in such cases.

Chest HRCTs were performed using different scanners, with the high resolution technique being utilized in all cases, with sections from the lung apices to the bases. Images were acquired using a slice thickness of 1 to $2 \mathrm{~mm}$, with the pa- tients in dorsal decubitus, during inspiration, utilizing a high spatial resolution filter for images reconstruction, with 10 $\mathrm{mm}$ increment, without intravenous administration of iodinated contrast agent. The images were obtained and reconstructed in a $512 \times 512$ matrix, digitized and photographed for evaluation of the lung fields with window width ranging between 1,000 and 1,500 Hounsfield units (HU) and level between -650 and $-750 \mathrm{HU}$. For evaluation of the mediastinum, the width of the windows ranged from 350 to 400 $\mathrm{HU}$, and the center between 40 and $60 \mathrm{HU}$. The analysis of the HRCT images was independently undertaken by two experienced thoracic radiologists, and the discordant results were resolved by consensus.

The following tomographic findings were analyzed: ground glass opacities, subpleural linear calcifications, small parenchymal nodules, calcifications along the interlobular septa, small subpleural nodules, nodular fissures, subpleural cysts, dense consolidations and crazy paving pattern.

The lesions distribution in the craniocaudal axis (upper, medium and lower) and in the axial axis (central, peripheral, without predominance), was also evaluated. The lung was divided along the craniocaudal axis from the apices to the level of the aortic arch; middle third, from the aortic arch up to $2 \mathrm{~cm}$ below the carina; and lower third, from $2 \mathrm{~cm}$ below the carina up to the costophrenic sinuses. The lesions were defined as central, when predominating in the internal third of the lungs, and peripheral, when predominating in the external thirds of the lungs, and also without predominance, when both locations occurred simultaneously.

Ground glass opacity was defined as increased pulmonary attenuation, with preserved bronchial and vascular margins.

Subpleural linear calcifications were described as such in those patients presenting with continuous linear calcified, juxtapleural opacities visible on the mediastinal window.

Small parenchymal nodules were characterized as round focal opacities measuring less than $10 \mathrm{~mm}$ in diameter.

The presence of calcifications along the interlobular septa was characterized in cases where linear, thin calcified opacities outlining the periphery of the secondary pulmonary lobe were visualized on the mediastinal windows.

Small, subpleural nodules were called small nodules along the pleural surface; and nodular fissures, as small nodules distributed along pulmonary fissures.

Consolidations were defined as being a homogeneous increase in the lung parenchymal attenuation coefficient, leading to loss of individualization of vascular structures and of airways walls. Consolidations were considered to be dense in cases where the density was greater than that of the soft tissues, as evaluated at the mediastinal window.

The crazy paving pattern was defined as the superimposition of ground glass opacities and interlobular septa thickening.

Subpleural cysts were defined as hypodense round structures measuring less than $10 \mathrm{~mm}$ in diameter, aligned next to the pleura. 
The criteria for definition of such findings were those listed in the Fleishner Society Glossary of Terms for Thoracic Imaging ${ }^{(4)}$ and the utilized terminology is presented in "Terminologia para a descrição de tomografia computadorizada do tórax" (Terminology for Description of Chest Computed Tomography) of Colégio Brasileiro de Radiologia (Brazilian College of Radiology ${ }^{(5)}$ and Comissão de Imagem da Sociedade Brasileira de Pneumologia e Tisiologia (Imaging Commission of Brazilian Society of Pneumology and Tisiology $)^{(6,7)}$.

\section{RESULTS}

In decreasing order of frequency, the following tomographic findings were observed: ground glass opacities $(n=$ $13 ; 100 \%)$ (Figure 1); small parenchymal nodules $(n=13$; $100 \%)$; small subpleural nodules $(n=12 ; 92.3 \%)$; subpleural cysts $(n=11,84.6 \%)$ (Figure 2$)$; subpleural linear calcifications $(n=9 ; 69.2 \%)$ (Figure 3$)$; crazy paving pattern $(n$ $=9 ; 69.2 \%)$; nodular fissure $(n=7 ; 53.8 \%)$; calcification along interlobular septa $(n=6 ; 46.2 \%)$; and dense consoli-

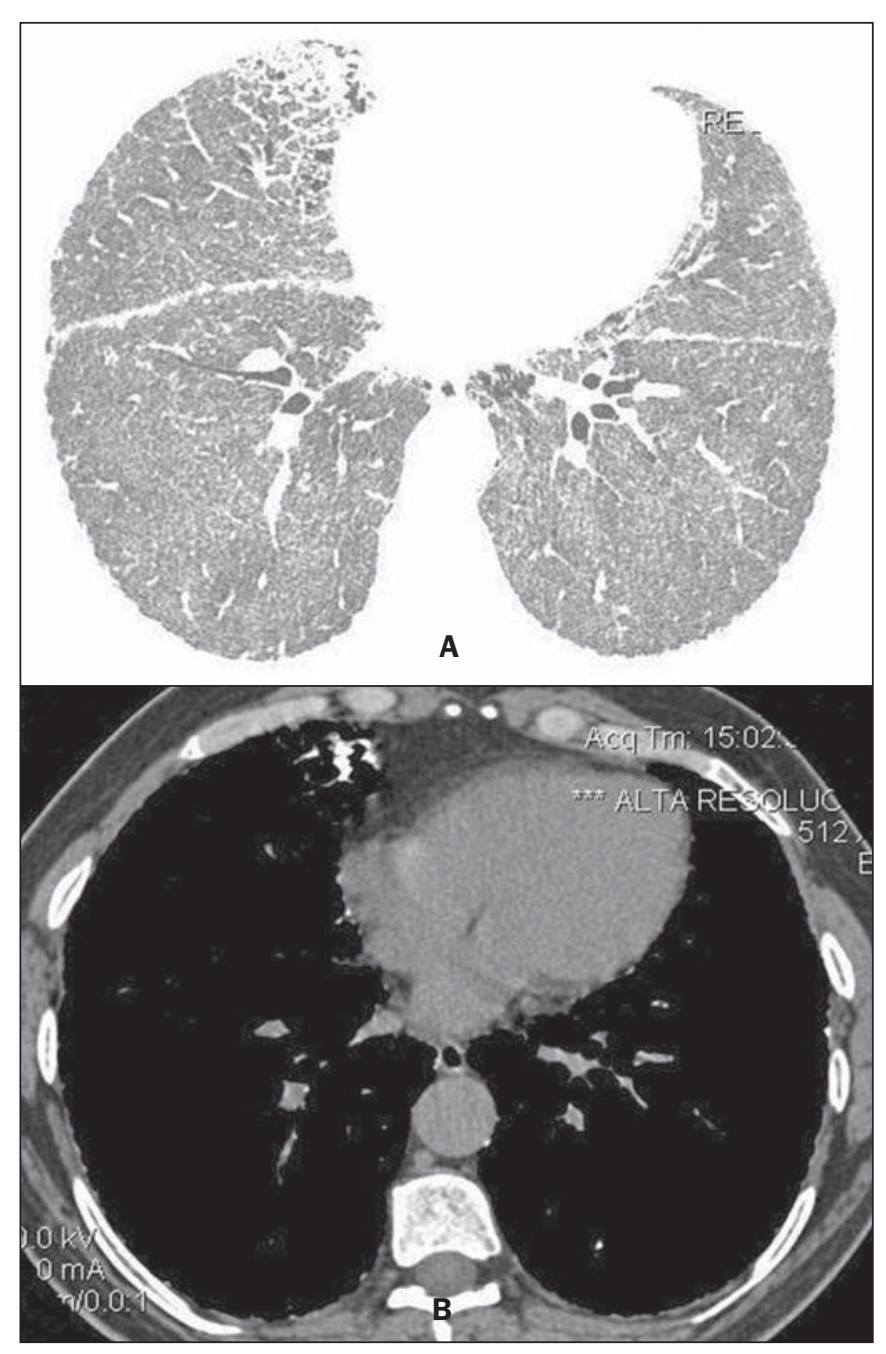

Figure 1. HRCT with lung windows setting shows (A) diffusely distributed ground glass opacities throughout the lungs, with consolidation in the middle lobe, besides nodular fissures. On mediastinal window (B) calcifications are observed in consolidations. dations $(n=6 ; 46.2 \%)$. Intermingled air bronchograms were identified in the 6 cases (Figure 4). As regards findings distribution, the lower third of the lungs was predominantly affected. No predominance was observed in distribution of findings in the axial and anteroposterior axis.

\section{DISCUSSION}

The imaging evaluation of the chest has been the subject of a series of recent publications in the Brazilian radiological literature ${ }^{(8-18)}$. With respect to PAM, studies analyzing large samples have not detected any gender predominance $^{(2)}$. In the present study sample, 9 patients $(69.2 \%)$ were women and $4(30.8 \%)$ were men. Such difference is possibly due to the limited number of studied patients.

As regards age at PAM diagnosis, studies demonstrated that the disease has already been described in patients of dif-

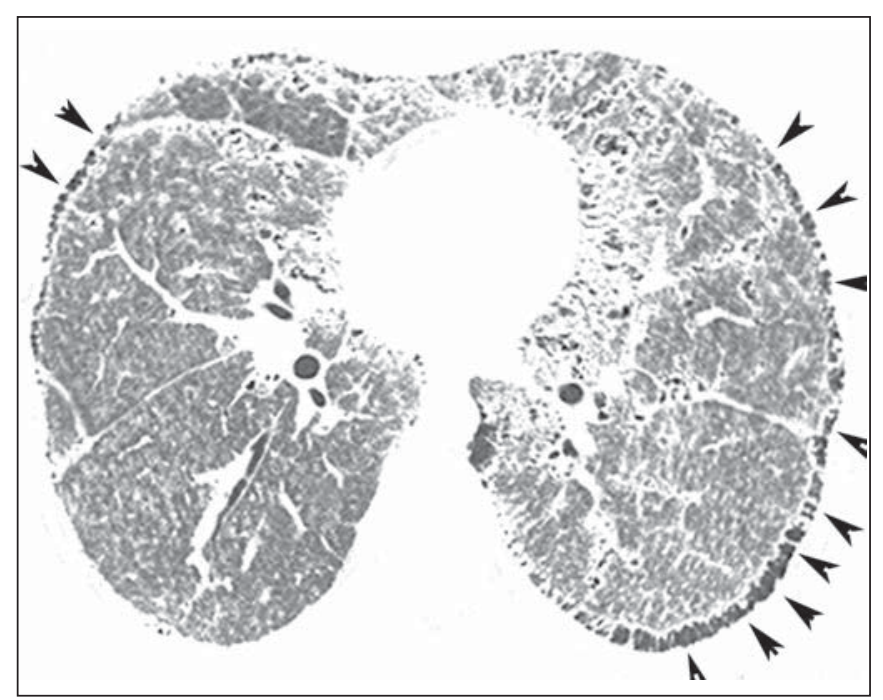

Figure 2. HRCT shows extensive, bilateral ground glass opacities diffusely distributed. Additionally, there are small subpleural cysts, more evident at the left (arrowheads).

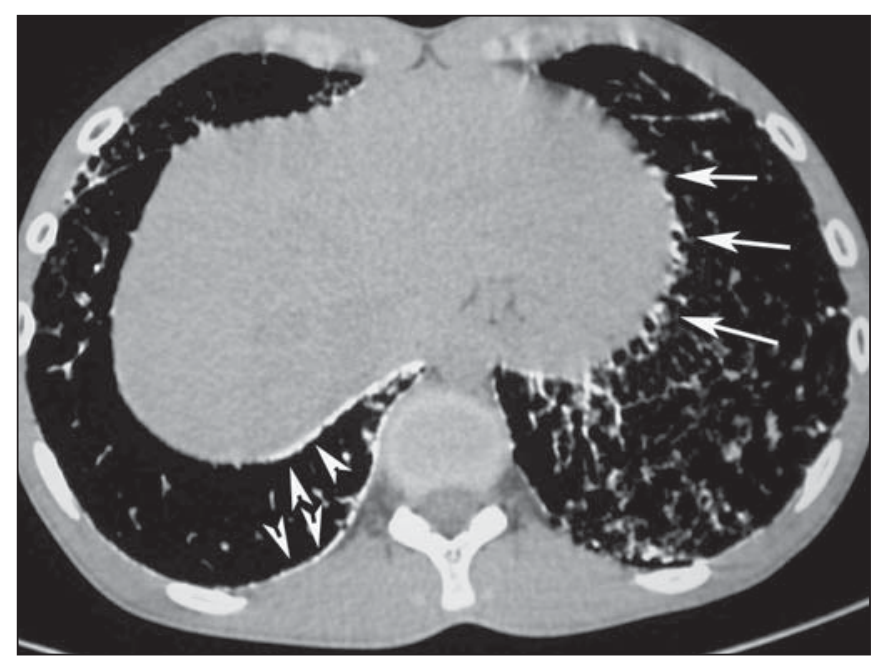

Figure 3. CT with mediastinal window demonstrating small calcified nodules with subpleural distribution (arrows) and subpleural linear calcifications (arrowheads). 


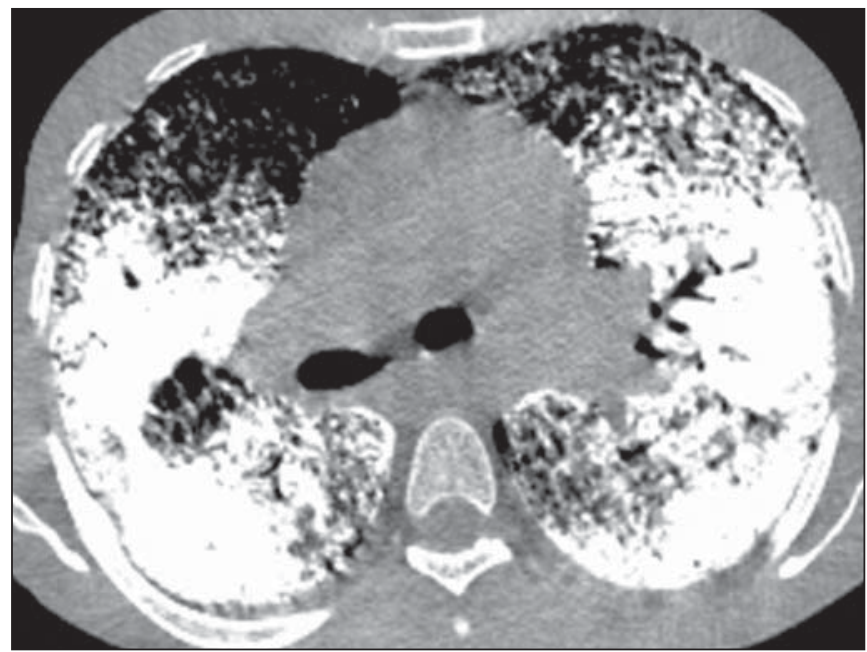

Figure 4. HRCT with mediastinal window demonstrating extensive consolida tions with calcium density and intermingled air bronchograms bilaterally distributed throughout the lungs.

ferent age groups, from children under one year of age to elderly patients ${ }^{(2,19)}$. In the literature, it was observed that $35.8 \%$ of the patients were less than 20 years old, while $88.2 \%$ were less than 50 years old ${ }^{(2)}$. In the present study, the ages ranged between 9 and 59 years, with a mean age of 34.5 years and median of 31 years, therefore our data was very similar to those found in the literature.

It is difficult to establish the age of PAM onset, as the time when it is diagnosed does not necessarily reflect the period when the disease started, because an important characteristic of this disease is the clinico-radiological dissociation, meaning that symptoms are scarce in contrast with the imaging findings ${ }^{(20)}$. Thus, many cases are diagnosed at imaging studies performed for other reasons, even in asymptomatic patients or, as the patient is symptomatic, the disease is diagnosed at more advanced stages ${ }^{(2,21)}$.

The affected individuals generally become symptomatic at the third or fourth decades of life. With the progression of the disease, which generally takes 10 to 20 years, cyanosis and digital clubbing are commonly observed. Dyspnea is the most frequent symptom, followed by dry coughing, chest pain, hemoptysis and asthenia, besides possible occurrence of pneumothorax ${ }^{(2,10,22-24)}$. Progressive deterioration of the pulmonary function may occur in adults, and death generally occurs in mid-adulthood because of respiratory failure with cor pulmonale ${ }^{(14)}$. On the other hand, cases of either static or very indolent disease have already been described ${ }^{(2)}$.

In approximately one third of the cases, PAM presents with a familial history, as it is a disease with recessive autosomal inheritance, indicating the importance of genetic factors in its genesis ${ }^{(1)}$. All PAM cases, either those of familial occurrence or the other two-thirds in the form of sporadic acquisition, present with mutation in the SLC34A2 gene, that is involved in the pathogenesis of the disease ${ }^{(3,24,25)}$.

Histopathological analysis reveals the presence of intraalveolar microliths. Sometimes, chronic inflammatory cells are present, and may induce interstitial fibrosis ${ }^{(26)}$. In some cases, microliths may be found in the sputum or in bronchoalveolar lavage, which can contain alveolar macrophages either with or without carbon particles ${ }^{(27)}$. With basis on HRCT findings, it is possible to confirm the diagnosis of PAM, many times avoiding lung biopsy ${ }^{(2,28-31)}$. In the present study, the diagnosis was based on typical chest HRCT findings. However, 6 patients were submitted to open lung biopsy, thus allowing histopathological confirmation. Once a given patient is diagnosed with PAM, family members should be screened by means of chest radiography, and parents should be advised that future daughters and sons are also at risk of developing the disease ${ }^{(28)}$.

The most frequent findings reported in literature include diffuse ground glass attenuation and subpleural linear calcifications. Other findings include: small parenchymal nodules; calcifications along interlobular septa, sometimes determining the crazy paving pattern; small subpleural nodules, nodular fissures, subpleural cysts and dense consolidations $^{(29)}$.

In the literature, ground glass opacities are reported as common findings, and probably occur due to the presence of small microliths in the air spaces ${ }^{(29,32)}$. In the present study, this was one of the main findings, present in all 13 cases $(100 \%)$.

Small parenchymal nodules were also identified in all 13 patients $(100 \%)$. At HRCT, small nodules at HRCT generally correspond to dense micronodules $(<3 \mathrm{~mm})$, diffusely distributed throughout the parenchyma, making the lungs hypotransparent and characterizing the pattern described by some authors as "sandstorm", that is considered as being typical of the disease. At HRCT, many times it is impossible to define the calcium density in the nodules, due to their small dimensions. However, when the microliths converge to form parenchymal consolidation, the calcium density can be better characterized, and is higher than soft tissues ${ }^{(23,29)}$.

Small subpleural nodules were observed in 12 of the cases $(92.3 \%)$ and nodular fissures were observed in 7 patients $(53.8 \%)$. These changes represent the accumulation of intra-alveolar microliths in the periphery of secondary lung lobes, adjacent to pleural surfaces, determining the feature of pseudopleural calcifications ${ }^{(33,34)}$.

Subpleural cysts represent another finding frequently reported in studies relying on HRCT. The small thin-walled cysts located in the subpleural spaces may determine the presence of a radiolucent line lying between the calcified parenchyma and the adjacent ribs, which is described in chest radiography as the "black pleural sign"(29,35). In the present study, subpleural cysts were observed in 11 patients $(84.6 \%)$.

Linear subpleural calcifications were found in 9 of the patients $(69.2 \%)$. This finding, in spite of being commonly seen at computed tomography in patients with PAM, is controversial in the literature. Although their description by some authors as pleural calcifications, there is no study reporting histopathological confirmation of pleural calcification. For 
that reason, the best explanation seems to be that such a finding is a consequence of the accumulation of intra-alveolar microliths in the periphery of secondary lung lobes, adjacent to the pleural surfaces, thus producing the pseudopleural calcification feature $^{(33,34)}$.

Calcifications along interlobular septa were observed in 6 patients, corresponding to $46.2 \%$ of the sample. Such a pattern occurs due to the deposition of microliths in the periphery of the secondary lung lobe, as there is no histopathological confirmation of calcification in interlobular septa or interstitial involvement at early stages of the disease ${ }^{(29,36)}$.

Crazy paving pattern was observed in 9 patients, representing $69.2 \%$ of the sample. This pattern is defined as areas of ground glass attenuation associated with interlobular septa thickening. It may also be observed on images at mediastinal windows due to the presence of calcifications along interlobular septa. There are no reports in literature about any other disease with similar tomographic manifestations. Thus, such HRCT findings are considered to be very specific and even pathognomonic of $\mathrm{PAM}^{(29,36)}$.

Confluence of small nodules may form areas of consolidation in the parenchyma, which, due to the presence of calcium, may have higher density than soft tissues. Dense consolidations predominantly occur in the cardiac margins, as well as in the lower and posterior regions of the lungs, tending to be symmetrical ${ }^{(23,34,35)}$. Dense consolidations with intermingled air bronchograms were found in 6 patients $(46.2 \%)$ in the present study. Therefore, PAM should be considered as a differential diagnosis for the dense consolidation pattern ${ }^{(23,29,34,35)}$, together with amiodarone pulmonary toxicity ${ }^{(37)}$, metastatic pulmonary calcification ${ }^{(38-41)}$, silicoproteinosis $^{(42,43)}$, talcosis $^{(44-46)}$ and amyloidosis ${ }^{(47-49)}$.

In PAM, lesions may be limited to determined areas or present with diffuse and symmetrical distribution throughout the lungs ${ }^{(21,23,29,34,35)}$. Calcium deposition in the alveoli generally starts in the lower lobes and takes the entire lung over a period of years, with evolvement to the middle thirds and then to the upper portions of the lungs ${ }^{(2)}$. The tomographic alterations are predominant in the lower and posterior portions of the lungs ${ }^{(29,34-36)}$. Additionally, the central portions of the lungs are more affected than the peripheral portions ${ }^{(35)}$. In the present study, all patients presented with bilateral distribution of tomographic alterations, without laterality predominance. Also, parenchymal lesions compatible with PAM were found in all lung lobes.

Studies describing tomographic findings in PAM are restricted either to isolated case reports, or to case reports with a small number of patients. There are no available studies evaluating radiographic findings in PAM with a large series of patients.

Our study has some limitations. The study was retrospective and the analysis was cross-sectional, without evaluating clinical and evolutive data. The techniques of HRCT varied according to the protocols from each institution involved in the study. However, such factors did not impair the analysis of imaging features, which was actually the aim of the present study. Despite these limitations, this is the largest reported series of HRCT findings in patients with PAM.

In conclusion, the most frequent tomographic findings were diffuse ground glass attenuation and small parenchymal nodules followed by small subpleural nodules, subpleural cysts, subpleural linear calcifications, crazy paving pattern, nodular fissure, calcification along interlobular septa and dense consolidations. In general, the findings predominated in the lower third of the lungs. The typical HRCT findings in PAM are so characteristic that, when present, can rule out the need for lung biopsy.

\section{REFERENCES}

1. Castellana G, Lamorgese V. Pulmonary alveolar microlithiasis. World cases and review of the literature. Respiration. 2003;70:549-55.

2. Mariotta S, Ricci A, Papale M, et al. Pulmonary alveolar microlithiasis: report on 576 cases published in the literature. Sarcoidosis Vasc Diffuse Lung Dis. 2004;21:173-81.

3. Huqun, Izumi S, Miyazawa H, et al. Mutations in the SLC34A2 gene are associated with pulmonary alveolar microlithiasis. Am J Respir Crit Care Med. 2007;175:263-8.

4. Hansell DM, Bankier AA, MacMahon H, et al. Fleischner Society: glossary of terms for thoracic imaging. Radiology. 2008;246:697722 .

5. Souza Jr AS, Araujo Neto CA, Jasinovodolinsky D, et al. Terminologia para a descrição de tomografia computadorizada do tórax (sugestões iniciais para um consenso brasileiro). Radiol Bras. 2002; 35:125-8.

6. Pereira-Silva JL, Kavakama J, Terra Filho M, et al. Consenso Brasileiro sobre Terminologia dos Descritores de Tomografia Computadorizada do Tórax. J Bras Pneumol. 2005;32:149-56.

7. Silva CIS, Marchiori E, Souza Jr AS, et al. Consenso brasileiro ilustrado sobre a terminologia dos descritores e padrões fundamentais da TC de tórax. J Bras Pneumol. 2010;36:99-123.

8. Amorim VB, Rodrigues RS, Barreto MM, et al. Computed tomography findings in patients with $\mathrm{H} 1 \mathrm{~N} 1$ influenza A infection. Radiol Bras. 2013;46:299-306.

9. Agnollitto PM, Barreto ARF, Barbieri RFP, et al. Rendu-Osler-Weber syndrome: what radiologists should know. Literature review and three cases report. Radiol Bras. 2013;46:168-72.

10. Marcos L, Bichinho GL, Panizzi EA, et al. Classification of chronic obstructive pulmonary disease based on chest radiography. Radiol Bras. 2013;46:327-32.

11. Koenigkam-Santos M, Paula WD, Gompelmann D, et al. Endobronchial valves in severe emphysematous patients: CT evaluation of lung fissures completeness, treatment radiological response and quantitative emphysema analysis. Radiol Bras. 2013;46:15-22.

12. Cerci JJ, Takagaki TY, Trindade E, et al. 2-[ $\left.{ }^{18} \mathrm{~F}\right]$-fluoro-2-deoxyD-glucose positron-emission tomography is cost-effective in the initial staging of non-small cell lung cancer patients in Brazil. Radiol Bras. 2012;45:198-204.

13. Canellas R, Kanaan D, Martins PHR, et al. Spontaneous regression of pulmonary alveolar proteinosis: a case report. Radiol Bras. 2012; 45:294-6.

14. Koenigkam-Santos M, Barreto ARF, Chagas Neto FA, et al. Neuroendocrine tumors of the lung: major radiologic findings in a series of 22 histopathologically confirmed cases. Radiol Bras. 2012; 45:191-7.

15. Zanetti G, Nobre LF, Mançano AD, et al. Pulmonary paracoccidioidomycosis. Radiol Bras. 2014;47(1):xi-xiii. 
16. Fernandes MC, Zanetti G, Hochhegger B, et al. Rhodococcus equi pneumonia in an AIDS patient. Radiol Bras. 2014;47(3):xi-xiii.

17. Mançano AD, Santos Neto RC, Silva KCC. Williams-Campbell syndrome. Radiol Bras. 2014;47(2):xi-xii.

18. Ceratti S, Pereira TR, Velludo SF, et al. Pulmonary tuberculosis in a patient with rheumatoid arthritis undergoing immunosuppressive treatment: case report. Radiol Bras. 2014;47:60-2.

19. Dahabreh M, Najada A. Pulmonary alveolar microlithiasis in an 8month-old infant. Ann Trop Paediatr. 2009;29:55-9.

20. Shah M, Joshi JM. Bone scintigraphy in pulmonary alveolar microlithiasis. Indian J Chest Dis Allied Sci. 2011;53:221-3.

21. Lauta VM. Pulmonary alveolar microlithiasis: an overview of clinical and pathological features together with possible therapies. Respir Med. 2003;97:1081-5.

22. Borrelli R, Fossi A, Volterrani L, et al. Right single-lung transplantation for pulmonary alveolar microlithiasis. Eur J Cardiothorac Surg. 2014;45:e40.

23. Korn MA, Schurawitzki H, Klepetko W, et al. Pulmonary alveolar microlithiasis: findings on high-resolution CT. AJR Am J Roentgenol. 1992;158:981-2.

24. Tachibana T, Hagiwara K, Johkoh T. Pulmonary alveolar microlithiasis: review and management. Curr Opin Pulm Med. 2009;15: 486-90.

25. Senyigit A, Yaramis A, Gürkan F, et al. Pulmonary alveolar microlithiasis: a rare familial inheritance with report of six cases in a family. Contribution of six new cases to the number of case reports in Turkey. Respiration. 2001;68:204-9.

26. Wallis C, Whitehead B, Malone M, et al. Pulmonary alveolar microlithiasis in childhood: diagnosis by transbronchial biopsy. Pediatr Pulmonol. 1996;21:62-4.

27. Monabati A, Ghayumi MA, Kumar PV. Familial pulmonary alveolar microlithiasis diagnosed by bronchoalveolar lavage. A case report. Acta Cytol. 2007;51:80-2.

28. Helbich TH, Wojnarovsky C, Wunderbaldinger P, et al. Pulmonary alveolar microlithiasis in children: radiographic and high-resolution CT findings. AJR Am J Roentgenol. 1997;168:63-5.

29. Marchiori E, Gonçalves CM, Escuissato DL, et al. Pulmonary alveolar microlithiasis: high-resolution computed tomography findings in 10 patients. J Bras Pneumol. 2007;33:552-7.

30. Abdalla G, Marchiori E, Zanetti G, et al. Pulmonary alveolar microlithiasis: a case report with emphasis on imaging findings. Case Rep Med. 2010;2010:819242.

31. Ferreira Francisco FA, Pereira e Silva JL, Hochhegger B, et al. Pulmonary alveolar microlithiasis. State-of-the-art review. Respir Med. 2013;107:1-9.

32. Schmidt H, Lörcher U, Kitz R, et al. Pulmonary alveolar microlithiasis in children. Pediatr Radiol. 1996;26:33-6.
33. Hoshino H, Koba H, Inomata S, et al. Pulmonary alveolar microlithiasis: high-resolution CT and MR findings. J Comput Assist Tomogr. 1998;22:245-8.

34. Cluzel P, Grenier P, Bernadac P, et al. Pulmonary alveolar microlithiasis: CT findings. J Comput Assist Tomogr. 1991;15:938-42.

35. Deniz O, Ors F, Tozkoparan E, et al. High resolution computed tomographic features of pulmonary alveolar microlithiasis. Eur J Radiol. 2005;55:452-60.

36. Gasparetto EL, Tazoniero P, Escuissato DL, et al. Pulmonary alveolar microlithiasis presenting with crazy-paving pattern on high resolution CT. Br J Radiol. 2004;77:974-6.

37. Hochhegger B, Soares Souza A Jr, Zanetti G, et al. An enlarged heart with hyperdense consolidation. Neth J Med. 2013;71:317-21.

38. Marchiori E, Müller NL, Souza AS Jr, et al. Unusual manifestations of metastatic pulmonary calcification: high-resolution CT and pathological findings. J Thorac Imaging. 2005;20:66-70.

39. Hochhegger B, Marchiori E, Souza Jr AS, et al. MRI and CT findings of metastatic pulmonary calcification. Br J Radiol. 2012;85: e69-72.

40. Bozi LCF, Melo ASA, Marchiori E. Pulmonary metastatic calcification: a case report. Radiol Bras. 2012;45:297-9.

41. Belém LC, Zanetti G, Souza AS Jr, et al. Metastatic pulmonary calcification: state-of-the-art review focused on imaging findings. Respir Med. 2014;108:668-76.

42. Marchiori E, Souza CA, Barbassa TG, et al. Silicoproteinosis: highresolution CT findings in 13 patients. AJR Am J Roentgenol. 2007; 189: 1402-6.

43. Souza CA, Marchiori E, Gonçalves LP, et al. Comparative study of clinical, pathological and HRCT findings of primary alveolar proteinosis and silicoproteinosis. Eur J Radiol. 2012;81:371-8.

44. Marchiori E, Souza Júnior AS, Müller NL. Inhalational pulmonary talcosis: high-resolution CT findings in 3 patients. J Thorac Imaging. 2004;19:41-4.

45. Marchiori E, Lourenço S, Gasparetto TD, et al. Pulmonary talcosis: imaging findings. Lung. 2010;188:165-71.

46. Pereira Faria H, de Souza Veiga A, Coutinho Teixeira L, et al. Talcosis in soapstone artisans: high-resolution CT findings in 12 patients. Clin Radiol. 2014;69:e136-9.

47. Marchiori E, Zanetti G, Hochhegger B, et al. Cystic amyloidosis or lymphoid interstitial pneumonia associated with amyloidosis? A diagnostic challenge. Ann Thorac Surg. 2012;94:1041-2.

48. Vieira IG, Marchiori E, Zanetti G, et al. Pulmonary amyloidosis with calcified nodules and masses - a six-year computed tomography follow-up: a case report. Cases J. 2009;2:6540.

49. Marchiori E, Franquet T, Gasparetto TD, et al. Consolidation with diffuse or focal high attenuation: computed tomography findings. J Thorac Imaging. 2008;23:298-304. 